\title{
Research
}

\section{Laryngomalacia: diagnosis and management at Otorhinolaryngology Head and Neck Surgery Department Dr.Soetomo Hospital, Surabaya}

\author{
Muhtarum Yusuf, Puji Utami \\ Department of Otorhinolaryngology Head and Neck Surgery \\ Faculty of Medicine Universitas Airlangga / Dr. Soetomo General Hospital, \\ Surabaya
}

\begin{abstract}
Background: Laryngomalacia is an abnormality of the larynx that leads to the inward collapse of the supraglottic structure during inspiration. The condition is primarily characterized by congenital stridor in infants and children. Diagnosis is often made based on the larynx visualization during inspiration. Laryngomalacia is generally recovers spontaneously at the age 2-5 years old, surgery is reserved for severe cases. Purpose: To obtain data of the clinical appearance, diagnosis, and therapy of laryngomalacia. Method: An observational study on medical records of all laryngomalacia patients at the Department of Otorhinolaryngology Head and Neck Surgery, Faculty of Medicine Universitas Airlangga/Dr. Soetomo General Hospital, Surabaya from January 1st, 2017 to December 31st, 2018. Data evaluation included clinical symptoms, type of laryngomalacia, comorbid factors, the age range of clinical improvement, and the management. Result: The main complaint of laryngomalacia was inspiratory stridor in 63 patients (82.89\%), followed by dyspnea, snoring, hoarseness, and choking. Endoscopy finding mostly was type 1 in 69 patients $(90.79 \%)$, the others were type 2 and 3. Comorbid factor mostly was neurological disease in 16 patients $(21.03 \%)$, followed by congenital heart disease, congenital abnormality, prematurity, and laryngopharyngeal reflux. The age group of clinical improvement majority were $<12$ months, followed by $>12-24$ months, and no improvement in 56 patients (73.69\%). Conservative therapy was conducted in 73 patients $(96.05 \%)$ and 3 patients were tracheotomized. Conclusion: The main complaint of laryngomalacia was inspiratory noises, mostly found was laryngomalacia type 1 . The highest comorbid factor was neurological disease. The most common management was conservative therapy.
\end{abstract}

Keywords: laryngomalacia, diagnosis, management

\section{ABSTRAK}

Latar belakang: Laringomalasia adalah kolapsnya struktur supraglotik laring saat inspirasi. Laringomalasia umumnya sembuh spontan pada umur 2-5 tahun, pembedahan hanya dilakukan pada kasus yang berat.Tujuan: Memperoleh gambaran klinis penderita laringomalasia, diagnosis dan terapi. Metode: Penelitian observasional pada semua rekam medik yang lengkap penderita laringomalasia di Departemen THT-KL RSUD Dr. Soetomo, Surabaya, periode 1 Januari 2017 - 31 Desember 2018. Data yang dievaluasi meliputi gejala klinik, tipe, faktor komorbid, usia perbaikan gejala, dan terapi. Hasil: Keluhan utama adalah napas berbunyi pada 63 penderita (82,89\%), disusul sesak napas, mengorok saat tidur, suara parau, dan mudah tersedak. Temuan endoskopik mayoritas tipe 1 pada 69 penderita (90,79\%), sisanya tipe 2 dan 3. Faktor komorbid terbanyak penyakit neurologis pada 16 penderita (21,03\%), disusul kelainan jantung bawaan, anomali kongenital, prematur, dan refluks laring faring. Usia perbaikan klinis mayoritas $<12$ bulan, diiikuti $>12-24$ bulan dan belum membaik 56 penderita (73,69\%). Terapi konservatif dilakukan pada 73 penderita (96,05\%) dan 3 penderita menjalani trakeotomi. Kesimpulan: Keluhan utama napas berbunyi, mayoritas laringomalasia tipe 1. Faktor komorbid terbanyak penyakit neurologis. Laringomalasia mayoritas diterapi secara konservatif. 
Kata kunci: laringomalasia, diagnosis, penatalaksanaan

Correspondence address: Muhtarum Yusuf, Department of Otorhinolaryngology-Head and Neck Surgery, Faculty of Medicine Universitas Airlangga / Dr. Soetomo General Hospital, Jl. Mayjen Prof Dr. Moestopo No 6-8 Surabaya. Email : muhtarumyusuf@yahoo.co.id

\section{INTRODUCTION}

Laryngomalacia is the term most widely used to describe the inward collapse of supraglottic structures of the larynx during inspiration. It is considered the most common cause of neonatal and infantile congenital stridor. $^{1}$

The incidence of laryngomalacia in the population is still uncertain, it is assumed that laryngomalacia occurred in one out of 2,100-2,600 infants. The pathogenesis of laryngomalacia remains obscure. The exact etiology of laryngomalacia is unknown and continues to be an area of great interest and research.

Several theories try to unfold the etiology of laryngomalacia, including the anatomic, cartilaginous, and neurologic theories. First the anatomic theory proposes that there is an abnormal positioning of flaccid tissue resulting in stridor. The second is the cartilaginous theory proposes that the cartilages of the larynx are immature and abnormally pliable. While the neurologic theory presumes that laryngomalacia might be a consequence of an underdeveloped or abnormally integrated central nervous system, particularly the peripheral nerves and brainstem nuclei responsible for breathing and airway patency. ${ }^{2}$

The typical presentation is inspiratory stridor and airway obstruction that worsen while eating, crying, agitation and supine position. Symptoms begin within the first 10 days of life and increase over the initial few months with a symptom peak at 6 to 8 months. Although most cases are benign, and self-limiting that resolves between
12 to 24 months of age, there are varying degrees of disease severity. Mild degree of laryngomalacia is when stridor only occurs sometimes, moderate degree has frequent feeding-associated symptoms of cough, choking, regurgitation, and cyanosis during feeding, while the severe degree have stridor and difficulty of breathing which needs surgical intervention. ${ }^{2,3}$

Diagnosis depends mainly on visualization of the larynx during respiration. This could be achieved by direct laryngoscopy or by means of flexible nasopharyngolaryngoscope (fiberoptic laryngoscope [FOL]). Short aryepiglottic folds, bulky redundant mucosa over the arytenoids cartilages and omega shapes epiglottis are the most common endoscopic findings in cases of laryngomalacia. ${ }^{1,2,4}$

There are 3 types of laryngomalacia, type 1 redundancy of arytenoid mucosa causing posterior collapse of the mucosa overlying the arytenoid cartilages, type 2 shortening of aryepiglottic folds causing lateral collapse of aryepiglottic folds, and type 3 drop in epiglottis in the anterior-posterior direction. ${ }^{5,6}$

The presence of medical comorbidities have impacts on symptoms and laryngomalacia disease course. Gastroesophageal reflux disease (GERD) and neurologic disease are the most common medical comorbidities. Other comorbidities are the presence of airway lesion, congenital heart disease, and the presence of a syndrome or genetic disorder. Laryngomalacia symptoms are usually mild, and conservative therapy will resolve the symptoms spontaneously by the age 2-5 years. The conservative therapy is executed with diet modification, nasogastric 
tube installation, anti-reflux, nebulizer, and routine follow up every 1-6 months for evaluation with FOL. Surgery is only performed with special indication such as severe upper airway obstruction with cyanosis attack, feeding difficulties and aspiration, weight loss and failure to thrive. ${ }^{1,2}$

The purpose of this research was to analyse overall data of laryngomalacia patients consisted of gender, age, main complaint, type, clinical appearance, comorbid factors, the age group of clinical improvement, and therapy at the Department of Otorhinolaryngology Head and Neck Surgery, Faculty of Medicine Universitas Airlangga/Dr. Soetomo General Hospital, Surabaya, from January 1 1, 2017 until December 31 2018.

\section{METHOD}

The research samples were complete medical records data of all laryngomalacia patients at the Department of Otorhinolaryngology-Head and Neck Surgery, Faculty of Medicine Universitas Airlangga/Dr. Soetomo General Hospital, Surabaya from January $1^{\text {st }}$,
2017 until December $31^{\text {st }}, 2018$. The research protocol had been approved by Dr.Soetomo General Hospital Ethic committee. Data evaluation included: age, gender, main complaint, age of clinical symptoms appearance, laryngomalacia type, comorbid factors, the age group of clinical improvement, and therapy.

\section{RESULT}

The study found 79 patients of laryngomalacia, and 3 of them were excluded due to incomplete medical records. Hence, 76 laryngomalacia neonates and infants were included in this research. The subjects were 41 males $(53.95 \%)$ and 35 females $(46.05 \%)$. The average mean age was 6.30 months with a span of the youngest age was 1 month, while the oldest was 36 months, and the majority was 2 months old ( 25 subjects). The main complaint was inspiratory stridor as many as $63(82.89 \%)$, dyspnea in $7(9.21 \%)$, snoring during sleeping in $4(5.26 \%)$, hoarseness in $1(1.32 \%)$, and easily choked in 1 subject $(1.32 \%)$ (Table 1$)$.

Tabel 1. Main complaints

\begin{tabular}{|c|c|}
\hline Complaint & Total number \\
\hline Inspiratory stridor & $63(82.89 \%)$ \\
\hline Dyspnea & $7 \quad(9.21 \%)$ \\
\hline Snoring & $4 \quad(5.26 \%)$ \\
\hline Hoarseness & $1 \quad(1.32 \%)$ \\
\hline Easily choked & $(1.32 \%)$ \\
\hline
\end{tabular}

The onset of symptoms appeared mostly in infants less than one month old 59 subjects $(77.63 \%),>1-6$ months in 12 subjects
$(15.79 \%),>6-12$ months in 3 subjects $(3.95 \%)$, and $>12$ months in 2 subjects $(2.63 \%)$.
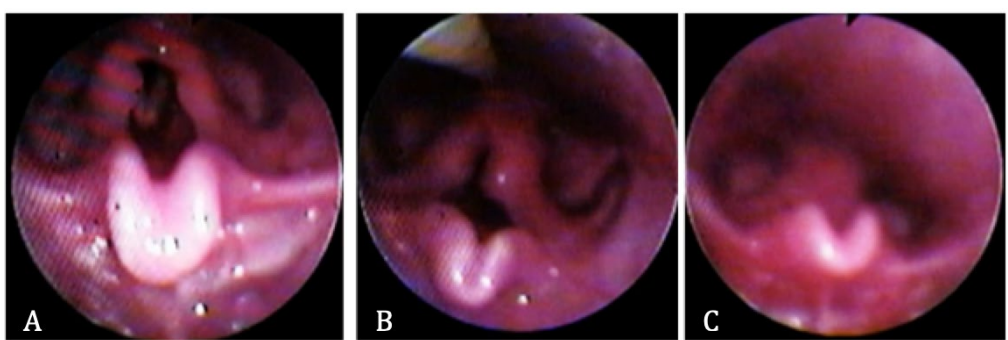

Figure 1. FOL view of laryngomalacia. A. type 1. B. type 2. C. type 3 
The diagnosis was established based on FOL examination with topical anesthesia. The endoscopic findings were type 1 laryngomalacia as many as 69 patients (90.79\%), 4 patients of type $2(5.26 \%), 2$ patients of type 3 (2.63), and 1 patient of combination type (1.32\%) (Figure 1).

The highest single comorbid factors was neurologic disease in 16 subjects $(21.03 \%)$, followed by congenital heart disease in 12 subjects $(15.79 \%)$, congenital anomaly in 8 subjects $(10.53 \%)$, premature birth in 5 subjects $(6.58 \%)$, and laryngopharyngeal reflux in 1 subject (1.32\%). In some subjects, there were combined comorbid factors such as of congenital heart disease and neurologic disease in $7(9.21 \%)$, laryngopharyngeal reflux and neurologic disease in 3 subjects (3.95\%), premature birth and congenital heart disease in 2 subjects $(2.63 \%)$, while subject without comorbid was 22 (28.95\%). (Table 2)

Table 2. Comorbid factors

\begin{tabular}{lc}
\multicolumn{1}{c}{ Comorbid factors } & Number \\
\hline Neurologic disease only & $16(21.03 \%)$ \\
Congenital heart disease only & $12(15.79 \%)$ \\
Congenital anomaly/syndrome & $8(10.53 \%)$ \\
Congenital heart disease + neurologic disease & $7(9.21 \%)$ \\
Premature & $5(6.58 \%)$ \\
Laryngopharyngeal reflux + neurologic disease & $3(3.95 \%)$ \\
Premature + congenital heart disease & $2(2.64 \%)$ \\
Laryngopharyngeal reflux only & $1(1.32 \%)$ \\
Without comorbid & $22(28.95 \%)$
\end{tabular}

Based on clinical symptoms and FOL examination, the highest number of clinical improvement was in $<12$ months 11 subjects (14.47\%), followed by in $>12-24$ months 5 subjects $(6.58 \%),>24$ months 4 subjects $(5.26 \%)$, and 56 subjects $(73.69 \%)$ with no improvement. The management consisted of conservative therapy and surgery, there were 73 subjects $(96.05 \%)$ on conservative therapy and 3 subjects $(3.95 \%)$ were tracheostomized. The conservative therapy is executed with diet modification, nasogastric tube installation, anti-reflux medication, nebulizer, and routine follow up every 1-6 months for evaluation with FOL. The surgical therapy performed were tracheostomy to clear the airway passage.

\section{DISCUSSION}

The subject of this research was 76 neonates and infants with laryngomalacia. The main complaint was inspiratory stridor- in 69 subjects. All subjects had stronger stridor in supine position and lessened while in prone or oblique body position. This was in accordance with literatures stating that stridor would worsen while breastfeeding, crying, supine position, being worried, and flexion of the neck. ${ }^{2,4}$

Feeding, exertion or agitation tends to increase stridor more clearly. Stridor will lessen with neck extension, prone position and calm respiration. Stridor is caused by the inward collapse of supraglottic structures of the larynx during inspiration. Other complaints include dyspnea, snoring, hoarseness, and easily choked. Babies with laryngomalacia have difficulties in sequence coordination of sucking, swallowing and breathing during breast feeding as a result of upper airway obstruction.,

Our research found that laryngomalacia symptoms occurred mostly in age group $<1$ month as many as 59 subjects (77.63\%), aged 
1-6 months in 12 subjects $(15.79 \%)$, aged 6-12 months in 3 subjects (3.89\%), and aged $>12$ months in 2 subjects $(2.63 \%)$.

Our research was in accordance with Ayari et al, ${ }^{4}$ that symptoms began within the first 10 days of life and increased over the initial few months. Stridor could worsen in the first month and began to slowly improve after one year of age, nevertheless stridor could also last for several years.

A research in Egypt 2011 by Fattah et al. ${ }^{1}$ reported 58 laryngomalacia cases with main symptoms of stridor and breastfeeding difficulties. Stridor occurred in day $5^{\text {th }}$ until 6 weeks postpartum. The slow onset could be explained by the average inspiratory flow after birth was not enough to produce noise, but with the baby growing development, the activity and air requirement increased. The premature neuromuscular control over supraglottic muscles explained the pathogenetic of laryngomalacia. This was shown by the symptom's improvement in several cases with subject's growing age. Infants with laryngomalacia could grow up normally and usually had no neurologic disturbance.

The diagnosis of laryngomalacia in this research was based on endoscopic findings using FOL with local anesthesia. Characteristic findings were short aryepiglottic folds, excessive arytenoid cartilage, and omega shaped epiglottis. Based on Olney's classification, the majority was type 1 found in 69 subjects $(90.79 \%)$, followed by type 2 in 4 subjects $(5.26 \%)$, type 3 in 2 subjects $(2.63 \%)$, and a combination was in 1 subject $(1.32 \%)$. This data was almost similar with other research where the majority was type $1(57 \%)$, type $2(15 \%)$, and type $3(13 \%){ }^{5}$

In this study, the highest comorbid was neurologic disease found in 42 subjects, including cerebral palsy, microcephaly, hydrocephaly, craniosynostosis, meningoencephalocele, meningocele, epilepsy, subdural hygroma and global development delay. Other comorbid was congenital heart disease in 16 subjects, congenital anomaly in 8 subjects, LPR in 4 subjects, and premature in 2 subjects. Subject with more than one comorbid was found in 12 subjects, comprised of 7 subjects with congenital heart disease and neurologic disease, 3 subjects with laryngopharyngeal reflux and neurologic disease, and 2 subjects with premature and congenital heart disease. Subjects without comorbid were 22. Other research reported that the highest comorbid was gastroesophageal reflux, followed by neurologic disease, secondary airway lesion, congenital heart disease, and congenital anomaly. $^{2}$

In this research, the improvement of laryngomalacia symptoms in the age $<1$ year were 11 subjects, improved in the age 12-24 months were 5 subjects, and improved after the age of 24 months were 4 subjects. The symptoms improvement based on FOL result and clinical symptoms was occurred in 20 subjects. There had been 56 subjects categorized without improvement, divided into 33 subjects due to unfinished evaluation time, and 23 subjects did not come for improvement evaluation. The 33 subjects with unfinished evaluation time was due to evaluation schedule was over the limit of research period.

Inspiratory stridor in laryngomalacia usually occurred in the first 2 weeks of life and symptoms peak at 6 to 8 weeks. The symptom will resolve spontaneously without treatment in 1 to 2 years of age. ${ }^{8}$ In general, laryngomalacia will resolve in $70 \%$ of subjects within the first year of life. Improvement happened gradually, first the stridor seldom occurred and later, stridor only occurred when agitated. ${ }^{5}$ In this research, the age of clinical improvement could not be concluded because many subjects could not be assessed from both causes of unfinished evaluation time and non-attending for evaluation. 
The majority in this research received conservative therapy as many as 73 subjects (96.05\%). The conservative therapy included diet modification, nasogastric tube installation, anti-reflux medication, nebulizer, and routine follow up every 1-6 months for evaluation with FOL. Tracheostomy was performed in 3 subjects $(3.95 \%)$, this procedure was implemented related to the improvement of the basic disease, not because of the worsening laryngomalacia symptoms.

Fattah et al. ${ }^{1}$ reported 58 cases, where 47 cases received conservative therapy and 11 cases underwent surgery. Out of 11 cases, 10 cases had supraglottoplasty, and 1 case underwent tracheotomy. The symptoms of laryngomalacia are usually mild and with conservative therapy, the symptoms will resolve spontaneously in 2-5 years of age. Surgery is only performed with special indication such as severe upper airway obstruction with cyanosis attack, feeding difficulties and aspiration, weight loss and failure to thrive. ${ }^{1,2}$

Supraglottoplasty proved to be effective and safe in the treatment of severe laryngomalacia. ${ }^{8}$

The result of this research concluded that the main complaint of laryngomalacia was inspiratory stridor, the majority symptom occurred within one month after birth. Diagnosis was based on nasopharyngolaryngoscopy examination using flexible fiber optic laryngoscope (FOL) with topical anesthesia. The majority cases found were type 1 laryngomalacia. The highest comorbid was neurologic disease. Most laryngomalacia cases in this study were treated conservatively.

\section{REFERENCE}

1. Fattah HA, Gaafar AH, Mandour MZ. Laryngomalacia: Diagnosis and management. Egypt J Ear, Nose, Throat Allied Sci. 2012; 12: 149-53.

2. LandryAM, Thompson DM.Laryngomalacia: Disease presentation, spectrum and management. Int J Pediatr. 2012; (2012): 1-6.

3. Thompson DM. Abnormal sensorimotor integrative function of the larynx in congenital laryngomalacia: A new theory of etiology. Laryngoscope. 2007; 117: 1-33.

4. Ayari S, Aubertin G, Girschig H, Van Den Abbeele T, Denoyelle F, Couloignier V, et al. Management of laryngomalacia. Eur Ann Otorhinolaryngol Head Neck Dis. 2013; 130: 15-21.

5. Olney DR, Greinwald Jr JH, Smith RJ, Bauman NM. Laryngomalacia and its treatment. Laryngoscope. 1999; 109: 1770-5.

6. Kusak B, Cichocka-Jarosz E, JedynakWasowicz U, Lis G. Types of laryngomalacia in children: interrelationship between clinical course and comorbid conditions. Eur Arch Otorhinolaryngol. 2017; 274(3): 1577-83.

7. Avelino MAG, Liriano RYG, Fujita R, Pignatari S, Weckx LLM. Management of laryngomalacia: experience with 22 cases. Rev Bras Otorrinolaringol. 2005; 71(3): 330-4.

8. Pamuk AE, Süslü N, Günaydın RO, Atay G, Akyol U. Laryngomalacia: patient outcomes following aryepiglottoplasty at a tertiary care center. Turk J Pediatr. 2013; 55(5): 524-8.

9. Pinto JA, Wambier H, Mizoguchi EI, Gomez LM, Kohler R, Ribeiro RC. Surgical treatment of severe laryngomalacia: a retrospective study of 11 cases. Braz J Otorhinolaryngol. 2013; 79(5): 564-8. 